\title{
ПоГЛЯДИ ШТІРНЕРА ТА НІЦШЕ НА ВЗАЕМОВІДНОСИНИ ОСОБИСТОСТІ Й ДЕРЖАВИ
}

\author{
I.C. Майорова
}

Там, де нема держави,-- дивіться ту. ди, брати мої!

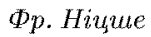

Українське суспільство останні півтора десятиліття переживае зміну ціннісних орієнтирів. В епоху «переоцінки цінностей» особливої актуальності для суспільства набуває об'єктивне осмислення філософських ідей тих мислителів, які довгий час оцінювались суто негативно. Зокрема це стосуеться й концепції індивідуалістичного анархізму. Слід зазначити, що українські дослідники чимало зробили у справі вивчення спадщини Фр. Ніцше (зокрема, Горбатенко В., Жкир В., Захарчук О., Коротіч Г., Осетрова О., Самардак М. та ін.), проте мало уваги приділяється саме його соціально-політичним поглядам, а також її порівнянню з ідеями такого оригінального мислителя, яким був М.Штірнер. Саме праця останнього «Єдиний та його власність» започаткувала індивідуалістично-анархічну течію. Анархісти зачислили Штірнера в отці-засновники класичного анархізму, однак сам він вважав себе «персоналістом». Слід також зазначити, що концепції обох мислителів мають багато спільного. Цікавим е той факт, що Макс Штірнер ще за сорок років до Фрідріха Ніцше закликав вирватися 3 пут моралі і піднятися над добром і злом.

Метою публікації є аналіз морально-етичних принципів, на яких будувалися погляди М. Штірнера та Фр. Ніџше на взаємовідносини особистості та держави.

Актуальні проблеми духовності

(Відн. ред.: Я.В. Шрамко)

Крнвнй Pir (2008), 162-170 
Німецький філософ-анархіст IIтірнер у « Єиному та його власності» поняття державної влади вживав у значенні впливу сили на особистість та суспільство: «Держава проявляе владу (насильство), одиничному це не дозволено. Діяльність держави полягае в насильстві; свое насильство вона називае „правом", насильство ж кожної особистості„злочином" $[15$, с. 234]. Держава постає носієм політичної влади, що експлуатуе громадян та маніпулюе і окремою особистістю, і суспільством в цілому. Для Штірнера кожна людська особистість (Єдиний) сама для себе $є$ цілим світом, джерелом права та моралі, має право жити і розвиватися як хоче, а все, що цьому протистоїть, він вважає ворожим.

Досить специфічно ШІтірнер трактуе й поняття права. Він вважав право породженням волі в суспільстві. Право існує завдяки пануванню над одиничним, а отже право - це воля повелителя. Штірнер не сприймав права як данину суспільства й пропонував джерелом права зроб́ити не державу, не Бога, не суспільство, а волю конкретного індивіда. Тільки вона може дати індивіду право: «Я сам вирішую-чи маю я на що-небудь право; поза мною немає ніякого права. Те, що мені здається справедливим, - i $є$ право» $[15$, с. 226]. Сучасне існуюче право філософ вважав «чужим», нав'язуваним. Існуюче право хибне хоча б тому, що воно дане тобі і не перевірене тобою самим на істинність. Так само і закони: за Максом ШІтірнером, усі закони, що регулюють людські дії, $є$ наказом та своєрідним чиїмсь волевиявленням. Штірнер наголошуе на тому, що ніхто не має права розпоряджатися чужими вчинками та диктувати той чи інший образ дій. Штірнер писав, що будь-який закон, що має регулювати людські стосунки, завжди $\boldsymbol{\epsilon}$ наказом. Він вважав неприпустимим те, що хтось має розпоряджатися чужими вчинками чи вказувати іншому на той або інший образ дій.

За Штірнером, власна воля індивіда та держава - два смертельні вороги. Звісно, державі надзвичайно вигідно та зручно, щоб ніхто не мав своєї волі. Якщо ж кожний буде мати свою окрему волю, то $є$ загроза тому, що тим самим вони зруйнують державу. Тому вище за індивідуальну волю ставиться в суспільстві воля державна і держава ніколи не відмовиться від того, щоб визначати волю одиничного, бо «коли зникае покорність, неминуче гине й панування» $[15$, с. 232]. Будь-яку вільну діяльність індивідів держава присікае і намагаеться подавити цензурою, оскільки це загрожуе її існуванню. I навпаки: дії, шляхи та думки індивіда мають бути спільними 3 державними, бо інакше вона «закрие йому рота» $[15$, с. 304]. Багато чого в державі $\epsilon$ підміною понять. Так, наприклад, свобода слова. «Яка користь вівцям 3 
того, що ніхто не обмежуе їх свободу слова? Все одно вони будуть лише блеяти» [15, с. 201]. За Штірнером, свободу не можна дати. Будь-яка свобода - це самовивільнення індивіда: він може мати стільки свободи, скільки здобуде її для себе завдяки своїй індивідуальності.

Так і уявлення про мораль повинно бути знищене і спростоване в людях, бо мораль - це певне схиляння перед чимось, приниження, підкорення, це прояв чогось вищого над найвишим - над конкретною особистістю. Немае цінності, що могла би бути вище, ніж найвища; а конкретна особистість - це найвища цінність. Тому все зовнішне, що приписується їй, затверджуюче свою цінність, свою значущість незалежно від її визнання, скасовується й спрощуеться. Моральне правило Штірнер розуміє як «зовнішне»; він розуміє «об'єктивність» морального закону як незалежність його значення від визнавання конкретної особистості, а це незалежне визнавання тлумачить в тому плані, що воно затверджене чиєюсь сторонньою, зовнішньою індивідууму волею.

Штірнер наголошує на тому, що нас було вигнано 3 нас самих. Він роз'яснюе це так: по-перше, нас знищуе держава; по-друге, сім'я відтворюе роль держави; по-трете, приватна власність використовуе тебе як охоронця. Крім цього, абсолютизовані у державі поняття права, обов'язку, суспільної думки, моралі і т. ін. покликані загіпнотизувати більшість людей та зменшити протест тих поодиноких, що протистоять масі загіпнотизованих.

Штірнер вважав усі види держави деспотією, навіть республіку. Він виступав за відміну усякої влади, за ліквідацію взагалі принципу влади в соціальному правлінні та пропонував замінити його самоорганізацією та самоуправлінням, оскільки людина самодостатня і не потребуе зовнішньої влади. Вона, за Штірнером, - єдине джерело насильства та несправедливості, тому ніколи не може бути виправдана. У цьому факті він вбачав найвищий прояв людської свободи та незалежності.

Щодо прогнозів стосовно організації держави нового типу та суспільства майбутнього, Макс Штірнер залишався на позиції негативізму. Варто наголосити на тому, шо Штірнер був теоретиком, кабінетним мислителем, і тому, можливо, не уявляв втілення своєї теорії на практиці, тому й вбачає майбутнє держави в «союзі егоїстів».

Фрідріх Ніџше створив власну аристократичну концепцію права та державності, в якій обгрунтував правомірність привілеїв, переваг та нерівності. Він відкидав ідею свободи та рівності у людських стосунках. У «Так казав Заратустра» Ніџше писав: «Справедливість каже мені так: „люди не рівні“. I вони не повинні бути рівними! Чим була б моя любов до надлюдини, якби я казав інакше?» [8, с. 103]. Ідеальна 
держава, за Фрідріхом Ніџше, має бути заснована на принципах аристократизму, де кожен займає строго відведене місце і служить ідеї «поліпшення роду». При цьому «сильніші» наділені правом і святим обов'язком розкрити свій потенціал, що, в свою чергу, має призвести до появи надлюдського типу. Ніцше за політичними поглядами $\boldsymbol{e}$ прихильником тиранії аристократії. Саме зі здоровою та сильною аристократією філософ пов'язуе життя і процвітання, а тиранія натовпу призведе лише до занепаду і смерті. Ніцше був непримиренним противником держави натовпу (демократичної держави). Подібно тому, як на зміну державі прийдуть нові інститути і заклади, нова правова система: «Ще більш досконалий заклад, ніж держава, отримає перемогу над державою» [9, с. 247]. Демократичні принципи Ніцше відкидав, вважаючи демократію історичною формою падіння держави і перепоною для появи ідеальної держави та надлюдини, оскільки вбачав у демократичному русі причини зменшення вартості людини і виведе-

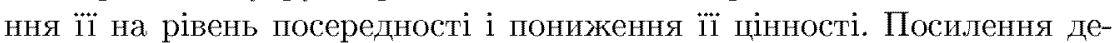
мократичних тенденцій у сучасному для Ніцше суспільстві мислитель пов'язував 3 так званим «повстанням рабів проти господ», 3 перемогою слабких над сильними, натовпу над особистістю. Для філософа неприпустимим було підкорення індивіда масі та знехтування індивідуальними відмінностями. Держава ототожнюеться Ніцше зі знищенням індивідуальності, перетворенням соціуму в стадо, знехтуванням у особистості «жадання влади». Таким чином, держава та особистість у філософській спадшині Ніцше постають ворогами, оскільки держава $\boldsymbol{e}$ виразником колективного (стада), а індивідуальність піддаеться нівелюванню.

Трохи пізніше іспанський мислитель Хосе Ортега-і-Гассет у книзі «Бунт мас» висловив схожі з Ніцше думки стосовно особистості, мас та суспільства. За Ортегою-і-Гассетом, маса - це «рядова людина». Маса - це кожний, хто сам не дає обгрунтованої оцінки - доброї чи злої, а натомість почуває, що він «такий, як усі», і проте тим не переймається і навіть «задоволений почуватися тотожним з іншими» [11, с. 142]. Філософ, подібно до Ніцше, поділяє людей на два типи: ті, що від себе нічого особливого не вимагають (маси) і ті, що багато від себе вимагають і беруть на себе нові труднощі та обов'язки (меншини). Хосе Ортега-і-Гассет зазначае, що у ХХ столітті маса вирішила висунутися на передній план суспільного життя та зайняти місця, що досі були призначені для небагатьох. Масса, констатуе мислитель, витіснюе меншини.

У трактаті «Людське, занадто людське» Ніцше зауважив, що полі- 
тика зводиться до того, щоб зробити терпимим життя як можна більшої кількості людей $[8$, с. 230]. За Ніцше, людська більшість - це людство, що перебуває у стані рабства: «кращі» люди, або каста «господ», цілком віддавалась владі глобального інстинкту - жадання влади, а раби виробили інші життеві цінності: любов до ближнього, смиренність і т.д. Моральні цінності у цьому контексті постають як засіб збереження суспільства. Спочатку для того, щоб змусити індивіда корегувати свою поведінку 3 інтересами суспільства, повинне застосовуватися насильство. Проте з плином часу насильство стає звичкою, а потім трансформується у те, що ми називаємо совістю. Ніцше не міг цього прийняти. Мислитель проголошуе свободу творчості у сфері моралі. Відстоюючи індивідуалістичні цінності, Ніцше стверджуе, що нові моральні цінності повинні мати автономний характер. На його погляд, добро та істина повинні бути для індивіда тим, до чого він сам має прийти, а не даним вже в готовому вигляді.

Дуже цікавою є оцінка феномена держави, котру Ніцше висловив вустами свого Заратустри: «Державою називають найхолоднішу з усіх холодних потвор. Холодно бреше вона, і ця брехня виповзае з вуст їі: Я, держава, і $\boldsymbol{\epsilon}$ народ» $[8$, с. 49]. Ідея надлюдини обгрунтована Ніцше 3 позиції захисту особистості від держави. «Держава пнеться стати найзначнішим звіром на світі» [8, с. 137] і Ніцше вбачае в цьому небезпеку породження та переваги недолугих та безпорадних. Ніџше критикуе державу як інститут. Разом із церквою він обвинувачує державу у лицемірстві. Однак, на відміну від Штірнера, Ніцше не відстоює свободу індивіда. На його думку, свобода недолугим останнім людям не потрібна, а надлюдина і так буде вільною. При цьому свобода для мислителя $\varepsilon$ цінністю, але в контексті його вчення про надлюдину свобода трактуеться як свобода духу, тобто внутрішня свобода індивіда (вільний не від чого, а для чого).

Саме свобода виступає однією з фундаментальних цінностей анархії. Це поняття є центральним, інтегруючим для всієї системи цінностей анархічного суспільства. Висунувши тезу про те, що свобода є засобом реалізації і розвитку людини, відбиттям його внутрішньої природи, теоретики анархії, виходячи 3 цього, трактують свободу, насамперед, як свободу волі, як можливість діяти відповідно до свого волевиявлення, недетермінованого зовнішніми умовами. Це і дозволило в подальшому ототожнювати анархізм із уседозволеністю. Проте, таке розуміння свободи характерно, в основному, тільки для найрадикальніших анархістів (ШІтірнер).

Позиція Ніцше стосовно нав'язуваних моральних цінностей інди- 
віду у державі збігається з поглядами Шттірнера на право. Філософанархіст не визнавав так званого «права у собі», оскільки воно існуе у суспільстві як вічна істина і не має жодного відношення до кожного конкретного індивіда. Права мають знаходитися не над індивідом (суспільні права), а бути виробленими ним самим: «Я не визнаю іншого джерела права, крім себе самого, Я не визнаю джерелом права-ні Бога, ні державу, ні природу, ні навіть Людину з їі „одвічними людськими правами", ні божественне, ні людське право» [15, с. 49].

Ніцше, як і ІІтірнер, не приймав Бога як одну з абсолютних цінностей. Їх концепції були виступами не тільки проти держави, але i проти всякої іншої установи, всякого закону, всякого авторитету, що підноситься над особистістю-як людського, так і божеського. Місце Бога в ієрархії вищих цінностей у обох мислителів займає особистість (у Штірнера - єдиний, а у Ніцше - надлюдина), що розуміється як своерідність кожної людини.

Переоцінка сутності соціальних інститутів та установ, включаючи державу і право, має у Ніцше футуристичне спрямування. У його творах ми знаходимо одне 3 найбільш продуманих вчень про владу XX ст. Минуло більше ста років зі смерті видатного мислителя, а у його ідеї стосовно того, що суспільство без держави все-таки буде володіти правом, е свої прихильники і сьогодні. Ніцше з його переоцінкою західноєвропейських цінностей вважається провісником нового типу мислення і світосприйняття, властивого ХХ ст.

Багато хто з дослідників творчої спадщини Фрідріха Ніцше звинувачував його у доведеному до крайнощів індивідуалізмі (Бердяев, Михайловський, Трубецький, Штейнберг та ін.). Процес індивідуалізаціі для Ніцше тісно пов'язаний з активною самореалізацією (творчість та самотворчість). У даному випадку індивід виступае у ролі центра, що організуе себе і своє життя, виробляе власні оцінки, цінності та погляди. Він наділений свободою вибору типу самореалізації, що дозволяє індивіду подолати родове та суспільне. Держава зі своїми інститутами та церква (як різновид держави) заважае џьому. Для Ніџше найвищою цінністю була надлюдина. У сучасному ж суспільстві такою є людина, індивідуальність. В.О. Кутирев зауважуе, що на початку ХХ ст. людське пізнання дійшло абсурду: «Ми проникли у світ настільки глибоко, що втрачаємо і його, і себе в ньому. Може, настав час повернутися? Якщо не взагалі, то вміти повертатися, коли необхідно. Але куди - до ілюзії? $[6$, с. 69]. Відповідь е: до філософської спадшини Ф. Ніцше, до ніцшеанської віри в унікальність, неповторність людини, в існування у неї творчого начала. Воля до життя спрямовуе людину на самовдоско- 
налення, до стану надлюдини: щоб вижити, відчути життя в усій його повноті, треба виховати в собі звичку постійно, кожного дня, повертатися до себе самого, постійно себе запитуючи: «Що я являю собою?», постійно розвиваючись, зміцнюючи свое фізичне та душевне здоров'я, виховуючи здібність самостійно, творчо мислити та діяти, усвідомлюючи відповідальності за власні вчинки. Творчість утверджуе людину в вічності, це і є повна реалізація «волі до життя» та власне людської сутності. Ніяка держава або доктрина не мають права стати на заваді цим процесам.

Отже, етико-політичний індивідуалістичний анархізм Макса Штірнера розглядае індивіда як самоціль, а у всебічному розвитку особнстості він вбачає кінцеву мету, а держава та суспільство розглядаються як допоміжні засоби для досягнення індивідом мети. Нині українська держава наслідуе світові демократичні тенденції, що призводить до зростання авторитету індивідуалістичних цінностей в суспільстві. Це дає змогу висувати на перший план абсолютну цінність людської особистості, а державу трактувати як засіб для забезпечення автономії індивідуальної волі.

Всупереч прогнозам Фрідріха Ніцше стосовно перемоги натовпу над особистістю у демократичному суспільстві, можна 3 впевненістю відзначити, що демократія не переслідуе інтересів натовпу, а навпаки, намагається створити 3 натовпу свідомих громадян.

Для Макса Штірнера суспільним ідеалом було анархічне суспільство, так званий «союз егоїстів». Штірнер за поглядами близький до демократії: він прагнув свободи і рівності для всіх. Ніцше ж-аристократ. Ідеалом для нього була держава Платона. Анархію як соціокультурний феномен було відкрито ще в добу стародавності. В ХХ столітті інтерес до анархії відродився після жахливих злочинів держави по відношенню до громадянського суспільства (нацизм, сталінізм, світові війни і т.д.). Для анархії характерний певний специфічний набір соціально-історичних цінностей, на вершині ієрархії яких знаходиться свобода. Той зміст, який теоретики класичного анархізму вкладають в складові ціннісної системи анархії, роблять тї відмінною від інших систем. Це ціннісні настанови суспільства, яке повинно забезпечити вільний та гармонійний розвиток кожної особистості.

Хоча під анархізмом досить часто розуміють насильницький антидержавний рух, він виступае за створення суспільства, заснованого на вільній співпраці індивідів. Анархія - це особливий реальний стан суспільства, в якому відсутня (як було до виникнення держав) або ж ослаблена державна влада, здійснюється «м'яка» державна участь 
у житті суспільства. Класики анархізму (насамперед, П.Ж.Прудон, М. Штірнер, М.О. Бакунін і П.О. Кропоткін) заклали фундамент уявлень про анархію як суспільство, яке $є$ позбавленим механізму примусової державної влади і яке створюе набагато більше можливостей для реалізації себе кожною особистістю. Анархізм спирається на принципи демократії, свободи і рівності та протистоїть будь-яким формам ісрархії. Не дивлячись на те, що анархізм не став пануючою ідеологією, він продовжуе знаходити прихильників різних національностей, віку та релігій, оскільки втілюе в собі споконвічне прагнення людини до звільнення від суворих обмежень у своїх вчинках, що накладає життя в суспільстві, організованому на державно-правових засадах.

\section{1 Бібліографія}

[1] Бондаренко О.В. Особливості соціально-філософського дослідження ментального феномену в аспекті «індивідуалізм-колективізм» // Мультиверсум. Філософський альманах. - К.: Центр духовної культури. - 2006. - №55.

[2] Горбатенко В. Про відторгнуті від музики слова: до осягнення державно-правових поглядів Фрідріха Ніцше // Людина і політика. - 2002. 츠. - С. 88-93.

[3] Ежсова E.A. Проблема власти, государства и права в философии М. Штирнера, М.А. Бакунина и П.А. Кропоткина // Вестник МГТУ, том 9.-ำ 1. -2006. - C. 41-52.

[4] Зыкова А.Б. Человек в философском учении Хосе Ортеги-и-Гассета // Буржуазная философская антропология XX века. - M., 1986. - C. 83-90.

[5] Корх О.М. Проблема індивідуалізму (історико-філософський аналіз). - Автореферат дисертації на здобуття наук. ступеня доктора філос. наук за спец. 09.00.05. - історія філософії. - Дніпропетровський національний університет. - Дніпропетровськ, 2002.

[6] Kутырев B.A. Апология человеческого (предпосылки и контуры консервативного философствования) // Вопросы философии.2002. - № 9 . 
[7] Мелих Ю.Б. Утверждение и осуждение индивидуализма у Ф. Ницше и В. Соловьева// Вопросы философии. -2002 . ․ㅡ 2. C. $97-102$.

[8] Hiчuе Ф. Так казав Заратустра; Жадання влади / Пер. 3 нім. А. Онишка, П. Таращука. - К.: Основи, 2003.

[9] Huцие Ф. По ту сторону добра и зла: Сочинения. - М.: Изд-во Эксмо; Харьков: Изд-во Фолио, 2003.

[10] Huише Ф. Так говорил Заратустра; К генеалогии морали; Рождение трагедии или Эллинство и пессимизм: Сборник / Пер. с нем., - 2-е изд. -Мн.: ООО «Попурри», 2001.

[11] Opmeza-i-Гассет X. Бунт мас // Всесвіт. - 1995. - ํo 1. - С. 141 154.

[12] Суико C.A. Человек и ценности в философии Н.А. Бердяева и Ф. Ницше // Вестник Московского университета. - 1991. - $₫ 6$. C. $61-71$.

[13] Чичнева E.A. Философско-правовые идеи в творчестве Ф.Ницше // Вестник МУ: сер. философия. - 2001. - № 6. - С. 65-73.

[14] Шевченко 3.B. Індивідуалізм як складова розвитку демократії.Автореферат дисертації на здобуття наук. ступеня кандидата філос. наук за спец. 09.00.03. - соц. філософія та філософія історії. Інститут вищої освіти Академії педагогічних наук України, Київ, 2005.

[15] ШІтириер М. Единственный и его собственность / Пер. с нем. Б.В. Гохшиллера. - СПб.: Азбука, 2001. 